\title{
Synergistic Effect of Organic Additives and Pulse-Current Plating in a Gold Electrodeposition Acid Bath and Gold Plating Film Corrosion Resistance
}

\author{
Makoto YUASA*, **, Takeo TSUTSUMI*, Yasuo MIYADATE*, \\ Yutaka OHTANI*, Isao SEKINE*, ** and Toshio KUZUSHIMA ${ }^{* * *}$ \\ 酸系電析金めっき浴での有機添加物および \\ パルスめっき法の相乗効果とその金めっき膜の耐食性
}

\author{
湯浅 真 ${ }^{*}{ }^{* *}$, 塘 健夫 ${ }^{*}$, 宮館康夫 ${ }^{*}$, 大谷 豊 ${ }^{*}$, \\ 関根 功 $^{* * *}$, 葛島俊夫 ${ }^{* * *}$
}

Key Words : Gold plating film, Electrodeposition, Organic additives, Pulse current plating, Corrosion resistance

\section{Introduction}

Gold plating films (0.05 to $0.75 \mu \mathrm{m}$ ) used in electronic parts such as connectors have been made as thin as possible to keep costs as low as possible ${ }^{1)}$, but the thinner the film, the lower its corrosion resistance due to the increased number of pinholes. Much work has gone into finding ways to raise corrosion resistance ${ }^{2) \sim 12)}$, including our previous reports on effective polymer additives in baths and efficient film sealing agents ${ }^{11)}{ }^{12}$. To find more effective citric acid baths for gold electrodeposition, we prepared baths containing organic additives such as pyridine derivatives and electrodeposited gold in these baths by pulse-current plating. We then studied the synergistic effect of organic additives and pulse-current plating and evaluated the film's corrosion resistance physicochemically.

\section{Experimental}

Materials...Pretreated copper and nickel-electrodeposited brass plates were used as substrates. Gold electrodeposition baths contained potassium dicyanoaurate ( I ) $\left(2.9 \mathrm{~g} \cdot \mathrm{dm}^{-3}, \mathrm{Au}\right.$ conc. $\left.2.0 \mathrm{~g} \cdot \mathrm{dm}^{-3}\right)$, citric acid $\left(100 \mathrm{~g} \cdot \mathrm{dm}^{-3}\right)$,

* Fac. of Sci. and Tech., Science Univ. of Tokyo (2641 Yamazaki, Noda-shi Chiba 278)

東京理科大学 理工学部

** Institute of Colloid and Interface Sci., Science Univ. of Tokyo (1-3 Kagurazaka, Shinjuku-ku, Tokyo 162) 東京理科大学 界面科学研究所

*** Electroplating Engineers of Japan Ltd. (EEJA) (5-50 Shinmachi, Hiratsuka-shi, Kanagawa 254) 日本エレクトロプレイティング・エンジニヤース（EEJA） cobalt ( II ) sulfate $\cdot$ heptahydrate $\left(1.0 \mathrm{~g} \cdot \mathrm{dm}^{-3}\right)$ and organic pyridine-derived additives such as 2-, 3- and 4-aminopyridine (functional groups : $\mathrm{NH}_{2}$; number of functional group : 1 ; abbrev. : $2,3$ and $4 \mathrm{AmPy})$, pyridine-3-sulfonic acid $\left(\mathrm{SO}_{3} \mathrm{H}\right.$; 1 ; 3 SulPy), 3-amidopyridine (nicotinamide, $\mathrm{CONH}_{2} ; 1 ; 3$ AmidPy ), 3-thioamido-pyridine (thionicotinamide, COSH ; $1 ; 3$ ThiPy) and 2, 3diaminopyridine $\left(\mathrm{NH}_{2} ; 2 ; 2,3 \mathrm{Am}{ }_{2} \mathrm{Py}\right)(0-0.1$ $\mathrm{mol} / \mathrm{L})$. Bath $\mathrm{pH}$ was maintained at 3.8.

Electrodepositions. '. Gold was electrodepos ited by direct current (DC, $2.0 \mathrm{~A} \cdot \mathrm{dm}^{-2}$ ) and pulsecurrent (PC, average current density $2.0 \mathrm{~A} \cdot$ $\mathrm{dm}^{-2}$, duty cycle $5 \%$ ) at $40^{\circ} \mathrm{C}$ and $1 \mathrm{~atm}$ with stirring. Films were about $0.3 \mu \mathrm{m}$ thick.

Measurements. $\cdots$ Relative film porosity was evaluated by potentiostatically electrolytic analysis ( $5 \%$ sulfuric acid, $+0.4 \mathrm{~V}$ vs. $\mathrm{SCE})^{12)}$. A nitric acid $\left(\mathrm{HNO}_{3}\right)$ exposure test was also done (conc. $\mathrm{HNO}_{3}, 30^{\circ} \mathrm{C}, 30 \mathrm{~min}$ ), and the ratio of corroded area (\%) was determined by ASTM D601-85 standard patterns. Gravimetry determined deposition efficiency ${ }^{13)}$. The surface and roughness of the plated film and its roughness were measured using laser microscopy and atomic force microscopy (AFM ; Digital Instruments, Nanoscope-III).

\section{Results and Discussion}

Gold plating film prepared without additives by DC (blank/DC) had many pinholes about $0.5 \mu \mathrm{m}$ in diameter. That electrodeposited without additives by PC (blank/PC) has fewer pinholes than blank/DC, and that deposited with additives by PC had significantly fewer pinholes. 


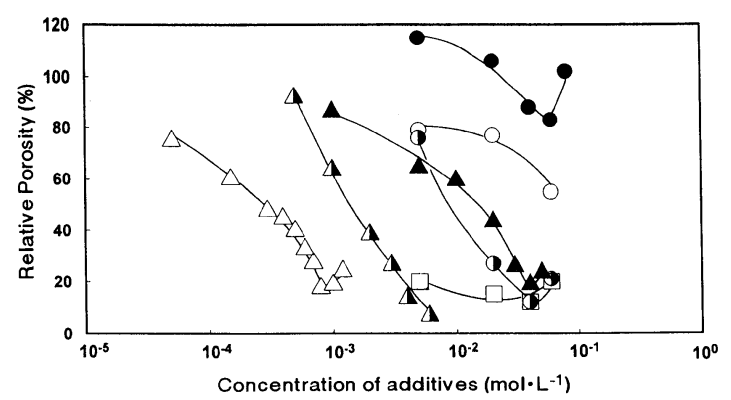

Fig. 1 Relationship between relative porosity and concentration of additives.
2AmPy, 3AmPy,
$4 \mathrm{AmPy}, \triangle 3 \mathrm{ThiPy}$

$\triangle$ 3AmidPy, $\triangle$ 3SulPy,

$2,3 \mathrm{Am}_{2} \mathrm{Py}$

Except for 3 AmidPy, films electrodeposited with additives, were not discolored. Baths with 3 AmidPy produced blue plating film.

The porosity of plating film in blank/PC decreased compared to that in blank/DC (relative porosity (\%) : blank/PC 100<blank/DC 611).

In the relationship between the concentration of additive and film porosity by PC (Fig. 1), porosity decreased with increased additives, particularly when slight amounts of 3ThiPy, 2,3 $\mathrm{Am}_{2} \mathrm{Py}$, and $3 \mathrm{AmPy}$ were added. In the $\mathrm{HNO}_{3}$ exposure test, the corrosion area ratio after electrodeposition by $\mathrm{PC}$ increased in the sequence 3ThiPy/PC $<3$ SulPy/PC $<$ additive-free/PC $<$ additive-free/DC. The corrosion area ratio corresponded to that of porosity.

Deposition efficiency was slightly less with PC than with DC (deposition efficiency $(\mathrm{mg} / \mathrm{A} \cdot \mathrm{min})$ : PC $10<\mathrm{DC} 12.5)$. In the relationship of deposition efficiency to additive concentration with PC (Fig. 2), deposition efficiency decreased with increased concentration except for $2 \mathrm{AmPy}$ and $4 \mathrm{AmPy}$, where porosity scarcely decreased. Only 2, 3Am ${ }_{2} \mathrm{Py}$ produced both lower film porosity and higher gold deposition efficiency.

AFM showed film surfaces prepared with additives other than $2 \mathrm{AmPy}$ and $4 \mathrm{AmPy}$ to be microscopically even and clean compared to those blank/DC and blank/PC. To quantitatively evaluate surface roughness, the center line average height $\left(\mathrm{H}_{\mathrm{cla}}\right)$ of film was determined by statistically analyzing AFM images. $\mathrm{H}_{\text {cla }}$ values of films prepared in baths with additives were smaller than in blank/DC and blank/PC $\left(\mathrm{H}_{\text {cla }}\right.$ (nm) : 3ThiPy PC 3.9, 2,3Am ${ }_{2} \mathrm{Py} / \mathrm{PC} 5.0$, 3SulPy /PC 5.8, 3AmidPy/PC 6.1, 3AmPy/PC 6.9, blank /PC 7.7 and blank/DC 9.1)

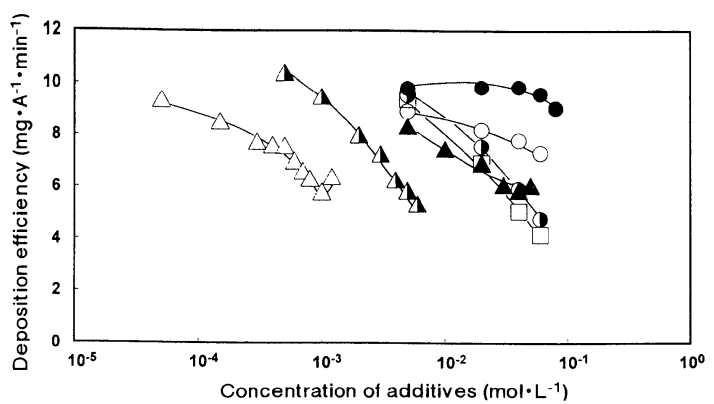

Fig. 2 Relationship between deposition efficiency and concentration of additives.

2AmPy, 3AmPy, 4AmPy, $\triangle 3$ ThiPy

$\triangle$ 3AmidPy, $\boldsymbol{\Delta}$ 3SulPy, $\square 2,3 \mathrm{Am}_{2} \mathrm{Py}$

Thus, using both additives such as pyridine derivatives and PC in citric acid bath systems effectively lowered porosity and increased deposition efficiency compared to using DC, additive /DC, and PC. Lower porosity and higher deposition efficiency were particularly obvious, thus confirming the synergistic effect of organic additives and pulse-current plating.

\section{References}

1) T. Shimojo and K. Ando ; Hyomen Gijutsu, 44, 1068 (1993)

2) I. Saito and H . Yoshida ; Hyomen Gijutsu, 43, 346 (1992)

3) K. J. Whitlaw ; a ) European Patent, GB 8334226 (1983), b) US Patent, 4591415 (1986)

4) P. Wilkinson and J. M. Mayne ; European Patent, GB 8501245 (1985)

5) J. A. Lochet ; US Patent, a) 4670107 (1987), b) 4744871 (1988).

6) K. Kubota and E. Sato; Kinzoku Hyomen Gijutsu, 35, 236 (1984)

7 ) W. Fluhmann, F. H. Reid, P. A. Mausli, and S. G. Steinemann; Plating and Surface Finish., 67, 62 (1980)

8 ) Y. Uchida ; Denshi-Tsushin Gakkai, Kiho Buhin Kenkyu Kai Shiryo, 82, 63 (EMC 82-60) (1982)

9 ) K. Sugimura ; Keidenki Kenkyu Kai Shiryo, 370-2 (1988)

10) I. Nakamura ; Japan Patent, 188282 (1991)

11) M. Yuasa, T. Kamogawa, Y. Ohtani, I. Sekine, S. Yarita, K. Tennichi, and T. Kuzushima ; Zairyo Gijutsu, 12, 111 (1994)

12) M. Yuasa, Y. Ohtani, I. Sekine, and S. Yarita ; Hyomen Gijutsu, 45, 657 (1994)

13) a) T. Kotoda ; Kikinzoku Mekki, p.84, Maki Shoten, Tokyo (1992), b) F. H. Reid and W. Goldie ; Gold Plating Technology (Electrochemical Publication, Apr. 1974) 